\title{
Correlation of Normal Peripheral Oxygen Saturation with Tea Likeliness
}

\author{
Muhammad Imran Qadir and Iqra Rafique* \\ Institute of Molecular Biology and Biotechnology, Pakistan \\ *Corresponding author: Iqra Rafique, Institute of Molecular Biology and Biotechnology, Pakistan
}

\begin{tabular}{|c|c|}
\hline ARTICLE INFO & ABSTRACT \\
\hline Received: February 06, 2019 & Summary \\
\hline Published: \# February 13, 2019 & The Aim of the present study was to correlate the blood oxygen with Tea likeliness. \\
\hline $\begin{array}{l}\text { Citation: Muhammad Imran Qadir, } \\
\text { Iqra Rafique. Correlation of Normal } \\
\text { Peripheral Oxygen Saturation with } \\
\text { Tea Likeliness. Biomed J Sci \& Tech Res } \\
\text { 14(3)-2019. BJSTR. MS.ID.002564. }\end{array}$ & $\begin{array}{l}\text { Blood oxygen level represents the fraction of oxygen i.e. saturation or unsaturation in hae- } \\
\text { moglobin of Erythrocytes. About } 200 \text { subjects took part in this study and Blood oxygen } \\
\text { level of every subject was checked by using Oximeter. The normal oxygen level in blood } \\
\text { of human beings should be } 97 \text { percent and it can fluctuate during exercise. Questionnaire } \\
\text { was prepared to estimate the likeliness and Dislikeliness among subjects. To analyze the } \\
\text { results, } t \text {-Test was done, and p-value was observed by considering p }<0.05 \text { as significant } \\
\text { value. By Statistical Analysis, it was interpreted from the recent study that Peripheral Ox- } \\
\text { ygen Saturation with Tea likeliness does not correlate. }\end{array}$ \\
\hline
\end{tabular}

Keywords: Blood Oxygen Level; Peripheral Oxygen Saturation; Tea Likeliness

\section{Introduction}

Blood oxygen level represents the fraction of oxygen i.e. saturation or unsaturation in haemoglobin of Erythrocytes. Blood should maintain normal levels of oxygen for aerobic metabolism which helps in Breathing. Human body needs specific oxygen level in blood and normal oxygen level in blood of human beings should be 97 percent and it can fluctuate during exercise. Haemoglobin of red blood cells collects oxygen in the lungs by using respiratory system and distributes it to the whole body. Oxygen level below 90 percent (low partial pressures of oxygen) leads to hypoxemia because hemoglobin is deoxygenated. The symptoms of low blood oxygen level include changes in the color of nails and skin i.e. bluish color appears. Blood oxygen level below 40 percent leads to compromise the function of Brain and Heart and Blood oxygen level below 20 percent leads to comma and ultimately, it causes death. Continue low levels of Blood oxygen causes many serious problems like cardiac, respiratory and neurological problems. A pulse Oximeter is an instrument which indicates the oxygen level in our blood. Oxygen therapy can be used to raise blood oxygen levels.

In ancient years, Tea was used as an aromatic beverage for many medicinal problems because it helps in improving our health i.e. it contains a chemical known as Nicotine. Now a days, Tea is also used to regulate the blood level of human beings because it has boosting antioxidants like catechins and ingredients which helps in the activation of human Brain and releases tension of the persons. Tea is simply prepared by the addition of teabags and milk in kettles of boiling water with a bit sugar according to one's taste. It is considered as White tea and it is the simplest tea. Tea is also considered as a lifestyle for the present generation. Many types of tea have been discovered yet i.e. White tea, Black tea, Green tea and Kashmiri tea etc. Black tea is considered as a strong tea because it contains potential ingredients in it and it is taken mostly in Europe. Green tea has its own great importance because it is taken as a diet tea i.e. it is helpful in the dieting. Kashmiri tea is used mainly in gatherings and it is used as a trend in Asian countries to serve Kashmiri chaye to guests. In short, Different types of tea have different nutritional and health values. By addition of Fruit flavors to the tea, we can get natural health benefits. We can also add the flavors of different things like chocolate. Tea has given us many benefits like it can reduce cancer related diseases and heart diseases. Furthermore, it gives us energy and refreshes our mind but excess of everything is bad. Therefore, we should not take more than 4 cups of tea per day. 
The aim of the recent study was to interlink the Blood oxygen level with Tea likeliness [1-5].

\section{Materials and Methods}

Approximately 200 participants took part in this research and Blood oxygen level of every participant was checked by using Oximeter. To interlink Peripheral oxygen saturation with Tea likeliness, Questionnaire was prepared to estimate the likeliness and Dislikeliness among participants.

\section{Estimation of Blood Oxygen Level}

Peripheral Oxygen Saturation represents the oxygen levels in blood, and it can be measured by using a device named Pulse Oximeter which clips to the finger or earlobe, light sensitive sensors in the device measure absorption of red and infrared light and it calculates the Blood Oxygen Level by finding the difference between oxygenated and deoxygenated hemoglobin levels in blood. By using a Formula, we can calculate the Blood Oxygen Level with Pulse Oximeter as follows:

$$
\mathrm{SpO}_{2}=\mathrm{Hbo}_{2} / \mathrm{Hbo} 2+\mathrm{Hb}
$$

Where $\mathrm{HbO}_{2}=$ Oxygenated Hemoglobin

$\mathrm{Hb}=$ Deoxygenated Hemoglobin

\section{Statistical Analysis}

Statistical Analysis was done by using state software. To analyze the results, $t$-Test was done, and p-value was observed by considering $\mathrm{p}<0.05$ as significant value.

\section{Results and Discussion}

t-Test was used to analyze the Correlation of peripheral oxygen saturation with Tea likeliness. In Table 1, Correlation of Peripheral Oxygen Saturation (Mean \pm SD) with Tea likeliness among males, females and Both (Males and Females) is given as follows in which p-value is calculated by $t$-Test is greater than 0.05 i.e. it is non- significant ( $p$-value smaller than 0.05 is referred as significant while $p$-value larger than 0.05 is referred as non- significant) and it means that there is no correlation of Peripheral Oxygen saturation with Tea likeliness [6-8]. This Questionnaire based studies will give great importance to the latest researches because no research has done before this about correlation of normal blood oxygen level with Tea likeliness. Such type of researches show advancement in the scientific era and give us broad idea to relate different variables with different Blood factors. In this way, we can also know about the diagnosis of different diseases related to human beings.

Table 1: Co-rrelation of Peripheral Oxygen Saturation (Mean \pm SD) with Tea likeliness among Males, Females and Both (Males and Females).

\begin{tabular}{|c|c|c|c|}
\hline Gender & Tea likeliness & Tea Dislikeliness & P-value \\
\hline Males & $96.76 \pm 4.56$ & $94.11 \pm 6.60$ & 0.14 \\
\hline Females & $95.62 \pm 7.27$ & $95.15 \pm 6.07$ & 0.74 \\
\hline Combined & $95.96 \pm 6.58$ & $94.92 \pm 6.12$ & 0.36 \\
\hline
\end{tabular}

Note: Results were non-significant $(\mathrm{p}<0.05)$.

\section{Conclusion}

By Statistical Analysis, it was interpreted from the recent research that Peripheral Oxygen Saturation with Tea likeliness does not correlate in human beings because $p$-value was larger than significant value which was calculated by using $t$-Test $(\mathrm{p}<0.05)$.

\section{References}

1. Qadir MI, Javid A (2018) Awareness about Crohn's Disease in biotechnology students. Glo Adv Res J Med Medical Sci 7(3): 062-064.

2. Qadir MI, Saleem A (2018) Awareness about ischemic heart disease in university biotechnology students. Glo Adv Res J Med Medical Sci 7(3): 059-061.

3. Qadir MI, Ishfaq S (2018) Awareness about hypertension in biology students. Int J Mod Pharma Res 7(2): 08-10.

4. Qadir MI, Mehwish (2018) Awareness about psoriasis disease. Int J Mod Pharma Res 7(2): 17-18.

5. Qadir MI, Shahzad R (2018) Awareness about obesity in postgraduate students of biotechnology. Int J Mod Pharma Res 7(2): 14-16.

6. Qadir MI, Rizvi M (2018) Awareness about thalassemia in post graduate students. MOJ Lymphology \& Phlebology 2(1): 14-16.

7. Qadir MI, Ghalia BA (2018) Awareness survey about colorectal cancer in students of M. Phil Biotechnology at Bahauddin Zakariya University, Multan, Pakistan. Nov Appro in Can Study 1(3): NACS.000514.2018.

8. Qadir MI, Saba G (2018) Awareness about intestinal cancer in university student. Nov Appro in Can Study 1(3): NACS.000515.2018.

\section{ISSN: 2574-1241}

DOI: 10.26717.BJSTR.2019.14.002564

Iqra Rafique. Biomed J Sci \& Tech Res

This work is licensed under Creative Commons Attribution 4.0 License

Submission Link: https://biomedres.us/submit-manuscript.php

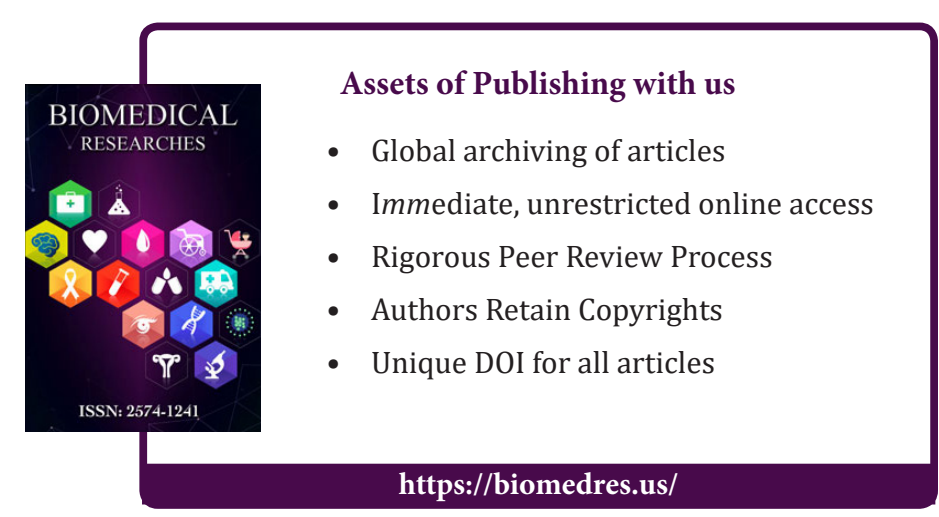

